\title{
Probing the grounds: Developing a payment-by-results agri-environment scheme in Finland
}

\section{Birge, Traci}

2017

Birge , T , Toivonen , M , Kaljonen , M \& Herzon , I 2017 , ' Probing the grounds: Developing a payment-by-results agri-environment scheme in Finland ', Land Use Policy, vol. 61 , pp. pÿ302 315 . https://doi.org/10.1016/j.landusepol.2016.11.028

http://hdl.handle.net/10138/308457

https://doi.org/10.1016/j.landusepol.2016.11.028

cc_by_nc_nd

acceptedVersion

Downloaded from Helda, University of Helsinki institutional repository.

This is an electronic reprint of the original article.

This reprint may differ from the original in pagination and typographic detail.

Please cite the original version. 
1 Title: Probing the Grounds: developing a payment-by-results agri-environment

2 scheme in Finland

3 Running title: Payment-by-results agri-environment scheme

4 Word count: Abstract $=206$, Main manuscript (incl. references, tables $\&$ figs) $=$

$5 \quad 10044$

6 Word count: Introduction: 1084; Materials and Methods: 2285 incl. 1 table; Results:

72638 incl. 3 tables \& 3 figures; Discussion: 1940; Conclusions: 269;

8 Acknowledgements: 54; References: 1774

9 Number of tables: 4 (+ Appendix Tables A1. \& A2.)

10 Number of figures: 3

11 Number of references: 65

12 Supplementary material: Appendix A 1 and A 2. Indicator species guide (English

13 common names) \& information to farmers (translated from Finnish); Table A1.

14 Indicator species; Table A2. Indicator species criteria for inclusion/exclusion;

15 Appendix B. Farmer interview guide; Appendix C. Expert stakeholder interview 16 guide. 


\section{Abstract}

Results-oriented approaches are widely regarded as an effective means to improving cost-effectiveness of agri-climate-environment schemes. We designed a hypothetical payment-by-results scheme for biodiversity conservation on environmental grasslands in Finland. The scheme would pay farmers a premium if the site contains a set number of indicator species, which were selected based on vascular plant surveys of the target habitat type. We presented the hypothetical scheme to 20 farmers and six experts (researchers, officials and advisors) in agricultural policy for their opinions on the payment-by-result approach generally and the hypothetical scheme specifically. The indicator species list proved suitable for identifying sites with high total species richness of vascular plants and also appeared feasible in the eyes of the farmers. Farmers were mostly positive about the approach and, mainly, thought their peers and society at large would receive it positively. The main concerns were about implementation, especially verifying the biodiversity results. People working for the national control body were the most critical and could not see how the hypothetical scheme could fit into the current institutionalised programme. Experience in other countries may provide solutions for overcoming such obstacles. The results are highly relevant for a discourse on social experimentation and cost-efficient delivery of public goods for public money.

Keywords: biodiversity, farmer interviews, indicators, outcome-based instruments, public payments, results-based schemes

\section{Highlights:}

- Potential for results-based agri-environment schemes is identified in Finland

- Indicator species work well in identifying most species-rich grasslands.

- Farmers are supportive of the results-based approach.

- Officials working in administration are most critical of the results-based approach.

- Main concerns with the approach are the implementation and verification of results.

\section{Introduction}

The agri-climate-environment schemes (AES) are the single most important tool for securing and improving the environmental and ecological state of the agricultural environments across the EU (EEA 2004, Batáry et al. 2015), including in Finland (Kaljonen 2011). As with any multi-objective policy tool, AES require constant development to remedy shortcomings. Among the most critical problem areas are the 
lack of incentives for achieving actual results, insufficient targeting, and difficulty in tailoring activities to diverse farm circumstances (e.g. Kleijn et al. 2011, Marggraf 2003, Whittingham et al. 2007, Arponen et al. 2013, McKenzie et al. 2013). The European Court of Auditors (2011) found that objectives of many AES were not specific enough for assessing whether or not they had been achieved. Furthermore, by paying participants a flat-rate remuneration for pre-specified management ("action" or "management" oriented approach), the current scheme design discourages participants from striving for innovative and site-specific approaches (Burton and Schwartz 2013, Kaljonen 2006 and 2008). The approach not only dis-incentivises farmers (Kaljonen 2006, Keenleyside et al. 2011), but makes their behaviour dependent on monetary stimuli at the expense of appreciation of results of their work (Herzon and Mikk 2007). Verification is entirely in the hands of officials, who are often perceived as a threat (Birge and Herzon 2014, Helenius and Seppänen 2004, Wilson and Hart 2001). It is a widely held expert view that AES need to become more results-oriented (European Network for Rural Development and EC 2010). The European Court of Auditors (2011) recommendations to the European Commission for improving efficiency of AES include more precise targeting of measures and clearer objectives; tailoring more demanding measures to local circumstances; and creating clear indicators for measuring success. The report specifically recommends examining the usefulness of outcome-based, or payment-by-results (PBR), measures (ibid, pp. 49). Such results-based agri-environment payments are already in use in several member states, including Germany, France and The Netherlands (comprehensive list in Allen et al. 2014). These include paying landowners or other managing bodies for defined biodiversity or ecosystem results, either exclusively or as a bonus on top of a payment for management actions. The payment may be based, for example, on occurrence of a number of indicator species. The commonest approach is of a so-called 'hybrid' type (ibid), where active management by farmers and/or a list of prohibited actions are part of the scheme requirements, but the payment rate is dependent on the ecological results. Among the perceived benefits of the approach, results-based remuneration is said to i) increase farmer intrinsic interest in achieving environmental objectives, ii) provide greater opportunity for innovation and site-specific solutions, iii) increase cost-effectiveness both in AES payment and in land-use practices for environmental results and, iv) build "social capital" (Burton and Paragahawewa 2011, de Snoo et al. 

2013, Klimek et al. 2008, Matzdorf et. al 2008, Swagemakers et al. 2009, Matzdorf and Lorenz 2010, Schroeder et. al. 2013). The latter refers to appreciation of farmer know-how in environmental management within the farming community and results in long-term change in farmers' behavior toward nature conservation.

In most cases, results-based agri-environment payments target botanically-rich grasslands (Allen et al. 2014). The results are easier to verify and monitor for biodiversity than for nutrient run-offs, for example (Berniger 2012, Allen et al. 2014, Table 7). Examples of result-based payments enhancing biodiversity include MEKA Baden-Württemberg Grassland Scheme in Germany (Matzdorf and Lorenz 2010, Matzdorf et al. 2010, EC 2015a), Prairies fleuries programme in France (De Sainte Marie 2014), Burren Life programme in Ireland (Burren Life 2015), and ÖkoQualitätsverordnung in Switzerland (Riedel et al. 2012). A similar approach to the Baden-Württemberg Scheme in Germany is under consideration in the UK (Schroeder et al. 2013). The payment level is linked to the occurrence of a progressively higher number of vascular plant species indicating extensive management and diverse plant communities. So far, there is no adaptation case of the approach to the northern agricultural environments, even if the potential benefits are large: In Finland, for example, production grasslands older than 5-years are rare (1.2\% of the utilized agricultural area; Natural Resources Institute Finland 2015), and semi-natural biotopes are fragmented remnants (Kemppainen and Lehtomaa 2009). However, uptake of AES is exceptionally high - $95 \%$ of agricultural land is under agrienvironmental commitments (Niemi and Ahlstedt 2014) (cf. 25\% in the EU-27, EC 2015b). Thus, AES have potentially very large impact on the ecological state of the agricultural environment.

Experience in developing and evaluating the indicators, as well as attitudes and skills of participating parties, are among the most important factors to consider in determining the feasibility of the result-based approach (Allen et al. 2014). In determining indicator species, preparatory research is needed because any indicator species list must be suitable for the target habitat and relevant to specific biogeographical regions, but also broad enough that it is inclusive of the whole area covered by the scheme (ibid).

The objective of this study is to develop and test two key issues in developing the results-based payment approach for biodiversity in Finland. We i) develop and assess 
121 the suitability of the biodiversity indicators, and ii) examine the range and

122 commonality of opinions and perceptions of farmers, experts and policy officials in

123 charge of the implementation of the agri-environmental schemes in Finland. We

124 developed a prototype for a PBR element in an existing AES, Nature Management

125 Grassland (NMG), based on experiences gained from other European regions with

126 PBR measures for biodiversity conservation (e.g. Bertke et al. 2008, Groth 2009, De

127 Sainte Marie 2014). We selected indicators based on data on vascular plants from two 128 previous studies in NMG fields (Toivonen et al. 2013, 2015). We further evaluated

129 suitability of the indicator list as, on the one hand, proxies for botanic diversity in

$130 \mathrm{NMG}$, and, on the other, as a tool for farmer participation in a potential PBR scheme.

131 Using the prototype as an example, we explored farmers', experts' and public

132 officials' opinions and perceptions about the proposed PBR measure. In our analysis

133 we focus on the following questions:

A. How well does the set of indicator species perform as a biodiversity indicator and as a tool for communicating with farmers and facilitating self-guided assessment?

B. Is the idea of results-based payment for biodiversity conservation in NMG field accepted in principle?

C. What are the perceived advantages and disadvantages of the prototype scheme presented, as compared to the existing management-based scheme?

D. What type of capacity building is identified as necessary for the scheme?

E. What is the perceived impact of the proposed scheme on reputation and public perception?

\section{Materials and methods}

\section{Developing the prototype}

We built the prototype upon the existing NMG (or grassland type of Environmental Fallow as in Toivonen et al. 2013) under the Finnish agri-environmental schemes. NMG fields correspond to extensive grassland, for which results-based payments have been run in Germany (Matzdorf et al. 2008, Matzdorf and Lorenz 2010), France (De Sainte Marie 2013) and Switzerland (Riedel et al. 2012), and are under consideration in the UK (Schroeder et al. 2013). NMG fields in Finland are 
established with grassland seed mixtures and are kept in place for at least two years.

Farmers can also enrol old grasslands as NMG without sowing. Management restrictions include prohibition of fertilisers and pesticides. Mowing is required every second year in all parcels. NMG fields can be used for production purposes, both as source of fodder and as pasture. However, NMG fields are frequently managed as arable fallows in which mown material may be left on site to decompose. Currently, the NMG scheme occupies $4 \%$ of the Finnish agricultural area and is present on $46 \%$ of Finnish farms (Natural Resources Institute Finland, pers. comm.). With permanent grass, the NMG scheme promotes both biodiversity and water protection. As a policy instrument, the NMG scheme is, however, considered one of the most important tools in enhancing common biodiversity in the agricultural areas (Kuussaari et al. 2013, Herzon et al. 2012).

Previous research demonstrated a considerable variation in plant species diversity among NMG fields (from 5 to over 50 species per field on a sample area: Toivonen et al. 2013). Many long-term NMG have highly naturalised vegetation (Herzon et al. 2012) and provide valuable habitats for butterflies, bumblebees and birds in the agricultural landscape (Toivonen et al. 2015, 2016). However, the current scheme does not distinguish between diverse old grasslands and rotational grasslands - from 2015 onwards, support is $100 € /$ ha to all parcels. Previously, inspectors considered natural vegetation as "weeds", and payment could be withdrawn on this basis (Finnish Agency for Rural Affairs, pers. comm.). Presently, the programming document explicitly states that naturalized vegetation is allowed. However, a requirement of obligatory mowing in cases of weeds remains vague since it is not specified which species constitute "weeds". Vague management guidelines such as these are one factor hindering the scheme from realising its considerable biodiversity potential. At its worst, excessive mowing at the peak of the breeding season may turn the grasslands into ecological traps (Battin 2004). The prescription-based scheme also sends a contradictory message that farmers on the one hand should manage to support biodiversity and on the other simultaneously avoid open-to-interpretation weed infestation.

We designed the test scheme as a hybrid scheme in which the baseline conditions for retaining the NMG for the minimum of two years and not applying chemical inputs would remain as they are presently. However, the bonus payment would be paid if the 

site were found to contain a set number of plant species indicating high nature value. Farmers would be responsible for self-monitoring twice during the agreement of five years. Results of the monitoring would be the basis for the normal subsidy application. The sites would be subject to normal agri-environmental inspection (i.e. a percentage of farmers are inspected annually and particular agreements verified). Extension services and materials for farmer and inspector capacity-building in species identification and best management would be available.

For developing the set of indicator plant species that correspond to Finnish conditions and type of vegetation under focus, we used botanical data from two previous studies (Toivonen et al. 2013, 2015). The studies ran on several types of environmental fallow fields but, for this work, we extracted the data only for the grassland option. In the first study, vegetation survey was performed in 104 NMG of various ages in three regions (Toivonen et al. 2013). Vascular plants were surveyed on one to four $12.5-\mathrm{m}$ transects per field (Toivonen et al. 2013). A total of 185 vascular plant species or pseudospecies were registered. In the second study, vegetation data were collected from $20 \mathrm{NMG}$ that were at least eight years old (Toivonen et al. 2015). There, vascular plants were surveyed on two 50-m long transects (Toivonen et al. 2015). The total number of registered species was 145 . The second study gave us a better understanding of the species pool on sites that are most likely to reach the diversity level required for the bonus payment, that is, relatively long-term NMG fields. In both studies, transects were placed systematically by the criteria agreed in advance, and vegetation was always sampled both along field margins (on the field side) and in the middle of the field (Toivonen et al. 2013, 2015). Full species lists from both studies are available in the respective publications.

Several criteria were used in selecting potential indicator species ( $c f$. Matzdorf et al. 2009, Magda et al. 2015): i) indication of species-rich communities and extensive management; ii) ease of recognition for a lay person with help of images; iii) species occurrence across the country and across a range of abiotic conditions typical for the field type; iv) frequency of occurrence in grassland communities of the focal field type; v) not a difficult agronomic weed. Details of inclusion and exclusion of specific species are presented in the Appendix Table A2.

The initial screening produced 42 species that correspond to the criteria above, of which we pooled several closely related species into species groups, as they can be 
confused by non-specialists (farmers) (Table A.1). The final list of indicator species included 24 species and species groups. Including both common and infrequent species would give most potential participants a chance of detecting at least a few of the indicators on most of the NMG fields and might motivate them to "achieve" more through adaptive management.

We designed a leaflet for farmers that outlines the bonus scheme and provides a visual tool to aid discussion and to function as a guide to the 24 indicator species (Appendix A). The guide has names and photographs of the indicator species.

For the statistical analysis, we used the data from the vegetation survey of 104 NMG fields in three regions (Toivonen et al. 2013). We related the mean number of indicator species per field with total species number, and with field number and area using linear correlation in IBM SPSS Statistics 23 (IBM Corp 2015). We evaluated the potential coverage of the fields qualifying for the bonus payment and potential budgetary expenses under alternative threshold values of a minimum number of the indicator species.

\section{Interviews and site visits}

We used a mixed methods approach (Creswell et al. 2003, Yin 2014) for assessing the responses of farmers, public officials and experts to the prototype scheme. The empirical material is composed of two sets: 1) semi-structured interviews and site visits for ecological observation with farmers from the Uusimaa region in southern Finland, and 2) semi-structured interviews and questionnaires with public officials and experts at multiple administrative levels (Appendices B and C - both interview forms). We based farmer selection on diversity and expert selection on known expertise in AES policy development, implementation and research.

\section{Farmer responses}

We chose the Uusimaa region for gathering the farmer responses because it is an important farming region of more than 3000 farms, the majority of which specialise in cereal production (1804 cereal farms in total) (Natural Resources Institute Finland 2016). NMG scheme is particularly relevant for farms without animal production 
250 because of its flexible management that does not require harvesting of biomass or

251 grazing of the sites (as is the case with grassed buffer zones). The scheme is also

252 especially important ecologically in cereal-dominated regions in which grassland

253 parcels are otherwise infrequent.

254 We selected farmers from a sample of 92 farms with NMG in Uusimaa Province

255 provided to us by the Information Centre of the Ministry of Agriculture and Forestry.

256 We selected farms with multiple NMG sites because these farmers would have broad

257 experience on various sites to draw on when assessing the prototype.

258 We sent letters to 47 farmers describing the research and inviting them to participate.

259 Eight farmers contacted us and we included them in the study. We telephoned the

260 remaining farmers for participation. To ensure variety between the farms, we grouped

261 the farmers by municipality to ensure geographic distribution and aimed to include

262 women, organic farms and livestock farms in our sample.

263 We reached a total of 33 farmers by telephone (a further 6 did not answer the calls),

264 resulting in another 12 interviews. Of the 33 contacted by telephone, 12 declined to be

265 interviewed, mainly due to time constraints, and 2 stated they would only be available

266 for interview after the growing season. Table 1 summarises the farmers interviewed

267 according to production type, farming "employment" status and number of NMG

268 parcels under management. Of the farmers interviewed, 9 were 30-49 years old and

26911 were aged 50-69 (mean age category: 45-50 years old). Primary production was

270 cereals for all except two of the farms. However, the farms included present the range

271 of farming contexts in the Uusimaa region, such as full vs. part-time farming, organic

272 vs. conventional production and fields situated far from the farmstead vs clustered

273 around the farm. Several of the cereals farms also had grazing animals.

\begin{tabular}{llll}
\hline $\begin{array}{l}\text { Primary } \\
\text { production type }\end{array}$ & $\begin{array}{l}\text { Full-time }^{1} \\
\text { farmers }\end{array}$ & $\begin{array}{l}\text { Part-time }^{2} \\
\text { farmers }\end{array}$ & Number of NMG fields (incl. rented) \\
\hline $\begin{array}{l}\text { Conventional, } \\
\text { cereals }\end{array}$ & 13 & $\begin{array}{l}\text { 5 (incl. the } \\
\text { only female } \\
\text { farmer) }\end{array}$ & Median: 7 \\
$\begin{array}{l}\text { Conventional, } \\
\text { specialty crops }\end{array}$ & 1 & 6 &
\end{tabular}


Organic, cereals 1

Organic, dairy 1
6
274

275

276

277

278

279

280

281

282

283

284

285

286

287

288

289

290

291

292

293

294

295

296

297

298

299

300

301

302

Table 1 Summary of the farmers interviewed.

${ }^{1}$ Full-time includes in some cases farm-based machinery operation businesses (e.g. snow ploughing, digging ${ }^{2}$ Part-time - primary employment is off-farm; includes self-described hobby farmer

\section{Farmer interview procedure}

We interviewed the farmers using an interview guide and key themes. We audio recorded the interviews with permission of the interviewees. Interview themes included attitudinal (e.g. willingness to engage with bonus payments, perceived benefits and problems), institutional (e.g. challenges in terms of administration and delivery, incl. advisory), and financial aspects (adequate level(s) of payments (Appendix B). We asked background information on the farm and farmer before continuing to discussion of current and past nature management and other possible AES contracts. We presented the prototype scheme to the interviewees and asked about their interest in such a scheme. We asked targeted questions about e.g. possible participation, feasibility of the presented idea and what would be needed for such an idea to succeed. We also asked how the farmer felt others (society and peers) would perceive the scheme. The final part of the interview focused on the interviewee's conceptualisation of "good farmer" and whether the NMG scheme fit into such a conceptualisation (Appendix B). Interview time averaged over 1 hour. We conducted interviews in Finnish, and in seven of the interviews a spouse or someone else involved in the farming participated for at least part of the interview. The majority of interviews (17/20) were conducted by two authors, with the same researcher leading the interview in all cases. In most cases (17/20), interviews were followed by a visit to an NMG field of the farmers' choosing, where we continued discussion of the proposed prototype as we walked across the field with the farmers looking for the indicator species.

\section{Public official and advisor interviews}


303 We chose experts based on their known expertise in administration or advisory of 304 AES and, specifically, AES for biodiversity conservation. Hence, in choosing the 305 public officials and experts, we did not use geographical determinants. We

306 interviewed representatives of the key actors, such as the Ministry of Agriculture and

307 Forestry, Agency for Rural Affairs, regional administration, advisory services,

308 Farmers' Union and environmental NGOs (altogether six interviewees). These

309 interviews focused on evaluating the potentials and possibilities of PBR measures in

310 the Finnish policy context. We contacted potential interviewees by telephone or email

311 and then sent them the background information and a set of questions. Afterwards we

312 met with respondents face-to-face or via Skype video call and discussed the issues.

313 One respondent preferred to send the response in writing and declined a request for a

314 meeting. Interviews took place after the farmer interviews. After interview questions,

315 we presented preliminary results from work with the farmers to see if it brought in

316 new themes and reactions from the expert stakeholders.

Analysis of the interviews

319 Analysis of farmer interviews started with a summarising practice similar to that 320 described by Schroeder et al. (2013, citing Mayring 2008) and was followed by a 321 modified version of theoretical thematic analysis (Braun and Clarke 2006) according 322 to the topics presented in Introduction. Firstly, we recorded our initial impressions of 323 the interviews immediately post-interview. At this stage we noted key points, new or 324 repeated information, and attitude toward the topic. We assessed how well the 325 interviewee understood the prototype scheme and how trustworthy their responses 326 were (veracity, how well-considered or thought-out). Secondly, we produced a 327 summary of the interview experience and key findings. Thirdly, we listened to the 328 interviews, produced partial transcriptions, and made note of the emerging themes, 329 answers to the quantitative questions, and the major points of the key themes 330 discussed. The dataset from experts and officials is shorter in comparison to farmer 331 interviews. For analysis, we extracted the key themes and points from the interviews.

332 We classified the quality of the fields visited with farmers into three categories for 333 likelihood of achieving the hypothetical bonus-payment, based on the number of the 334 indicator species: i) "meets requirements" (seven or more indicator species), ii) "could 
meet requirements with reasonable effort" (less than seven indicator species but a field is suitable in terms of its history and current vegetation type), and iii) "highly unlikely to meet requirements without considerable effort" (few, if any indicator species, high cover of species indicating nutrient-rich conditions or dominated by commercial seed plants).

\section{Results}

Indicator species evaluation

The mean number of the suggested indicator species per NMG field was 3.2 and maximum was 11 species. The number of indicator species strongly correlated with total number of vascular plant species per plot (Pearson $r=0.745, \mathrm{p}<0.000$; onetailed) (Fig. 1). The number of indicator species also positively correlated with field area (Pearson $r=0.318 \mathrm{p}<0.001$; one-tailed).

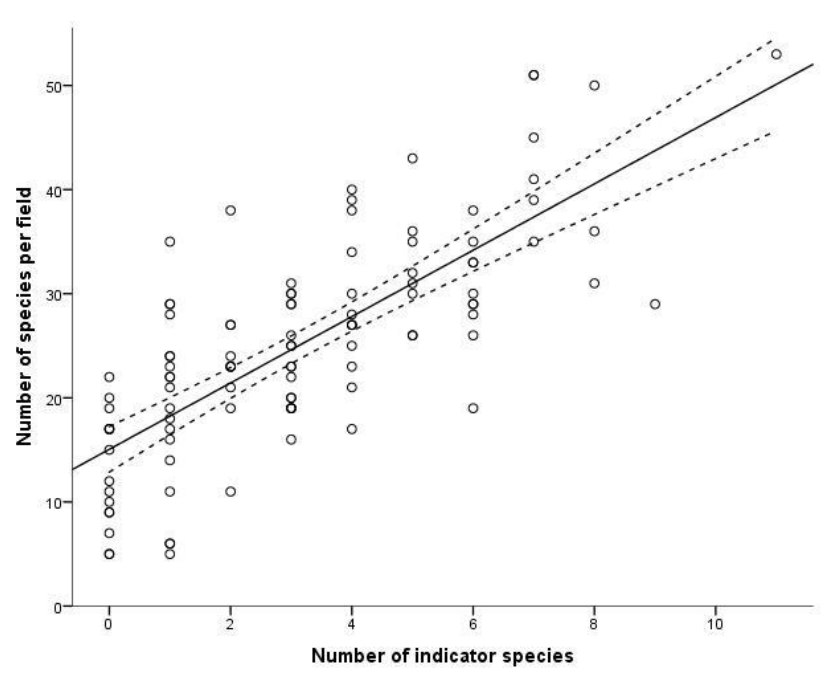

Fig. 1. Linear correlation between number of vascular plant species per field and number of indicator species in nature management grasslands in Finland. The vegetation data come from Toivonen et al. (2013) $(\mathrm{n}=104)$.

The percentage of the number of fields that would qualify for the bonus payment and their combined area linearly declined with increasing threshold number of indicator species (Fig. 2). With six species as a threshold, the eligible number of fields would consist of about $20 \%$ of the total NMG parcels and $30 \%$ of the combined area. With 
seven species as a threshold, about $10 \%$ of fields, covering $10 \%$ of NMG area, would have qualified.

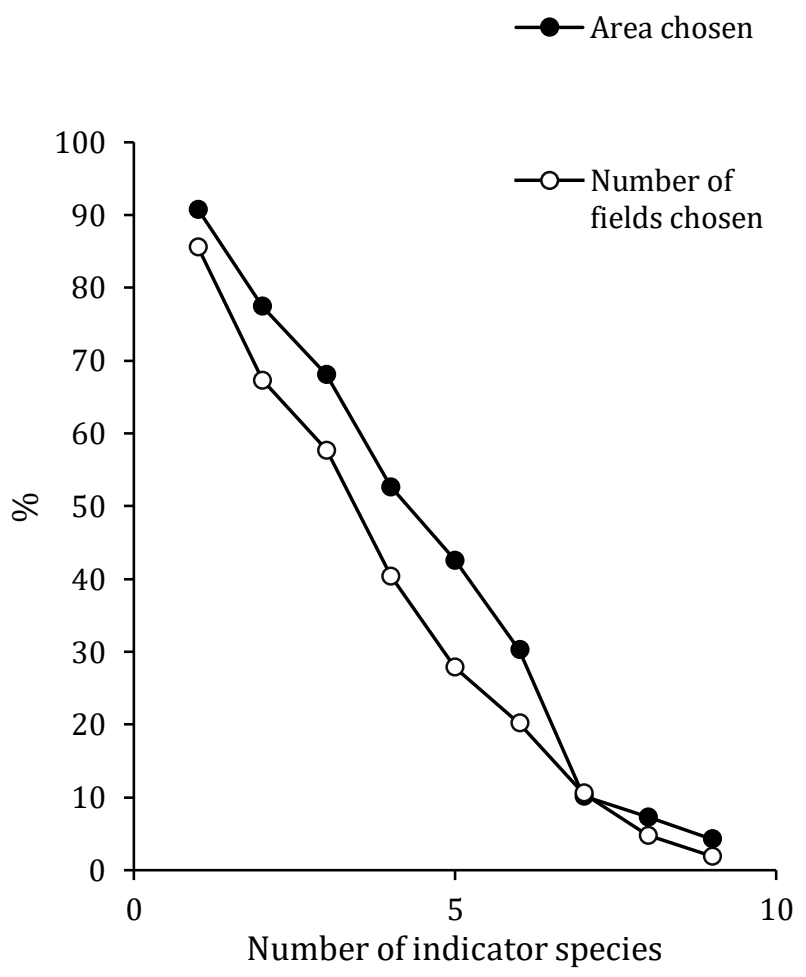

Fig. 2. Percentage of the a) number of nature management grassland fields and b) their area that would have qualified for the bonus payment based on a progressively increased threshold number of the indicator species. Vegetation data comes from Toivonen et al. (2013) $(\mathrm{n}=104)$.

Mean number of plant species was 25 species for all fields. Fields which would have qualified for the bonus payment based on the threshold of seven indicator species had on average 42 species per field.

Modelling of the potential eligible area for the bonus payment and resulting budgetary expense demonstrated that the optimum of biodiversity gain (in terms of local species numbers) related to the expense is in the threshold of seven species (Fig. 3). If the bonus payment is set at, for example, $50 €$ per hectare, the NMG measure would draw an additional 0.5 million $€$ from the agri-environmental programme. This would channel about $5 \%$ of the total current expenditure on the measure to retention and management of parcels with nearly double mean species richness per plot compared 
to the scheme overall. The costs of paying the bonus can also be related to species as a unit of biodiversity. In this case, bonus for fields would target from 59 to 182 species accumulated over the whole fields potentially chosen (Fig. 3). The cost per unit in both cases drops at seven indicator species.

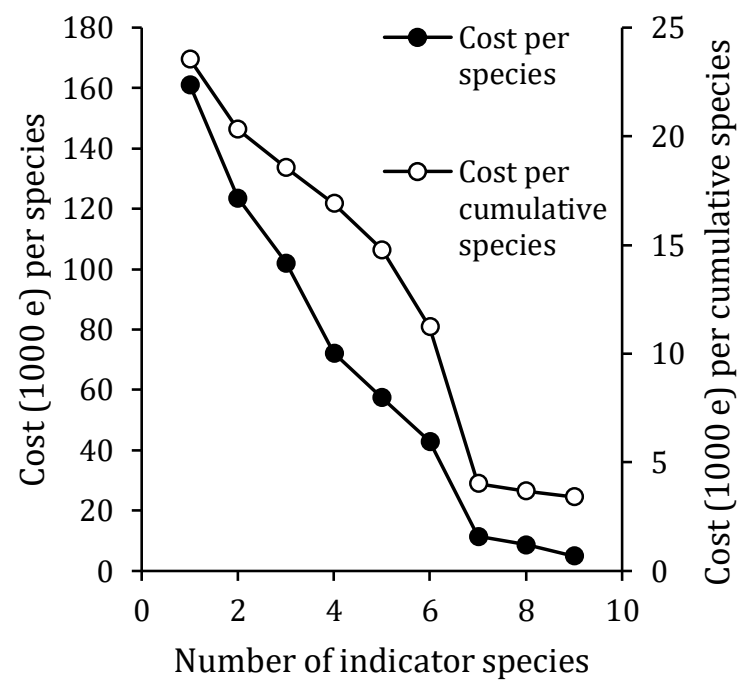

Fig. 3. Budgetary expense for the premium payment related to a) the mean number of species and b) the cumulative number of species in the potentially chosen fields, as a function of the threshold number of indicator species. The bonus payment is set to $50 €$ per hectare. Vegetation data comes from Toivonen et al. (2013) $(\mathrm{n}=104)$.

\section{Farmer participation in the NMG scheme}

Farmers' reasons for participating in the NMG scheme were mainly related to convenience and low production value of the fields: NMG were often small, wet, oddly shaped, highly shadowed by forest, or far away from the farmstead (cf. Herzon et al. 2012). Most of the farmers had long-term NMG, and some also established NMG as part of their crop rotation. Farmers commonly adjusted to a greening requirement under the Common Agriculture Policy for the Ecological Focus Area by placing some of the former NMG into this obligatory field type. This practice was common amongst grain farms lacking other land use (e.g. pasture, leguminous crops) to fulfil the requirement.

\section{Farmer acceptance of the potential payment-by-result option}


Initial farmer responses to the PBR prototype scheme fell into three categories: immediate positive attitude (14), immediate negative attitude (2) and equivocal (4)

400 (sample of responses in Table 2). Eight farmers used 'smart', 'interesting/interested' or 'good' in their response. Rather than giving a clearly positive or negative response,

402 'equivocal' farmers responded with questions, such as how to establish the indicator

403 species and how inspection/documentation would work in practice. Negative

404 responses were based on the scheme being perceived as 'too bureaucratic'. There was 405 no clear difference based on ages, farm size or education level.

406 The farmers, in general, approved of the idea of payments being linked to specific 407 results. It was generally regarded as a fair approach. Farmers mainly were not able to 408 propose their own measures to achieve the biodiversity goal proposed here. Some 409 farmers (as well as experts) compared the approach to another scheme that targets 410 semi-natural vegetation on so-called traditional rural biotopes and noted that the 411 bonus measure for NMG has fewer management demands and, thus, a lower threshold for participation.

414 Table 2 Sample of the initial responses from farmers to the proposed bonus scheme, including 415 description of the farmer and whether the nature management grassland visited was suitable for the 416 bonus. Response classifications are positive (pos), negative (neg), and equivocal (equiv).

\begin{tabular}{|c|c|c|c|}
\hline $\begin{array}{l}\text { Farmer } \\
\text { description: } \\
\text { age, sex, field } \\
\text { area, other work }\end{array}$ & $\begin{array}{l}\text { Field's } \\
\text { suitability } \\
\text { for the } \\
\text { bonus } y / n^{*}\end{array}$ & $\begin{array}{l}\text { Response } \\
\text { class }\end{array}$ & First impressions \\
\hline $\begin{array}{l}\text { Over } 35,100 \text { ha } \\
+ \text { another } \\
\text { business }\end{array}$ & $\mathrm{y}$ & Pos & $\begin{array}{l}\text { An interesting idea. It would bring more income } \\
\text { but also more biodiversity... also more work. I } \\
\text { would consider it. }\end{array}$ \\
\hline Over 60,42 ha & $\mathrm{n}$ & Pos & $\begin{array}{l}\text { Why not? Farmers have done stranger things to get } \\
\text { subsidies than count flowers. }\end{array}$ \\
\hline Over 35,150 ha & $\mathrm{n}$ & Pos & $\begin{array}{l}\text { It sounds smart. Now when they've been mown } \\
\text { it's not necessarily so good for those plants. }\end{array}$ \\
\hline $\begin{array}{l}\text { Over } 50, \text { female, } \\
35.5 \text { ha }+ \\
\text { employed full } \\
\text { time off-farm }\end{array}$ & $\mathrm{y}$ & Pos & $\begin{array}{l}\text { It doesn't sound like such a big job. We go out } \\
\text { walking there sometimes anyway. }\end{array}$ \\
\hline Over 30,255 ha & $\mathrm{y}$ & Pos & $\begin{array}{l}\text { Could be interesting. Clearly different than what } \\
\text { has come before. For example, I've never been told } \\
\text { about these [indicator] plants before. }\end{array}$ \\
\hline $\begin{array}{l}\text { Over } 45,150 \text { ha } \\
+ \text { heavy }\end{array}$ & $\mathrm{y}$ & Equiv & $\begin{array}{l}\text { The nature management fields are so } \\
\text { different...some of them sure, there's plenty of }\end{array}$ \\
\hline
\end{tabular}


machinery job

off-farm

Over 40,260 ha $\quad \mathrm{y}$ species, others-there's not much without sowing the seeds and then the cost has to be compensated.

Payment is, of course interesting, but my first impression is that it sounds too bureaucratic. The whole AES scheme already has so many nuances and different directions.

$* \mathrm{y}=>7$ indicator species found during site visit

\section{Farmer concerns or reasons not to accept payment-by-result}

420 Concerns focused on the proposed prototype, rather than payment-by-result approach generally, and mainly on implementation in practice (Table 3). The main concern was verifying the results in a consistent way for both farmers and inspectors. Farmers suggested several technical or management-based solutions, such as documenting indicator species by taking gps \& time-stamped photos on smart phones and creating 'sections' within parcels to pinpoint species for special management for conservation (indicator species) or control (e.g. thistles). A farmer who was formerly an inspector for the state agency overseeing agriculture subsidy payments was initially highly critical of the approach for its lack of prescribed management actions, asserting that farmers need rules to follow and inspectors need actions to evaluate.

Table 3 main concerns about results-based approach brought up by the farmers. The most common concern is in bold.

\begin{tabular}{|c|c|}
\hline Theme & Concerns \\
\hline \multirow[t]{2}{*}{ Cost } & Where will the money come from for farmer training? \\
\hline & $\begin{array}{l}\text { Will the bonus cover the cost of purchasing seeds, extra management, loss } \\
\text { of other crop/land use? }\end{array}$ \\
\hline Farmer capacity: knowledge & Learning new management skills to propagate, identify, target species \\
\hline Farmer capacity: time & Time commitment- more effort for management \\
\hline Extension & $\begin{array}{l}\text { Will the training be sufficient, what kind of support (contact information, } \\
\text { materials) will there be? }\end{array}$ \\
\hline Inspection \& verification & Farmer \& inspector must have same criteria and result. \\
\hline \multirow[t]{2}{*}{ Governance } & Commitment to contract \& options if it doesn't work out. \\
\hline & $\begin{array}{l}\text { Farm planning period, including subsidy applications, vs. knowing if site } \\
\text { successfully meets the requirements; }\end{array}$ \\
\hline Land use & If bonus is too attractive, good farmland could be taken out of production; \\
\hline & Aesthetics, appropriate 'placement' for NMG; \\
\hline
\end{tabular}


Long-term NMG becoming sources of noxious weeds;

Peer perceptions

Do not want to stand out as doing something different.

Implementation: prerequisites and capacity building

435 Though the approach would not stipulate management, most farmers were keen to

436 receive advice for best management. Some voiced specific concerns about

437 neighbours' disapproval of "weeds" or neglect of sites. Three farmers stressed the role

438 of good marketing and packaging of the measure for farmer acceptance.

439 Among the farmers, being unsure about best management practices and associated

440 work for improving the nature value of the NMG was more of a concern than carrying

441 out self-monitoring of indicator species. Many farmers did not see species monitoring

442 as a burden, with some pointing out that they walk in their fields regardless and others

443 saying that it can be a pleasant break to go out in the field on a nice day to look for the

444 indicator species and that it could even be done with their children or grandchildren.

445 Most farmers were able to correctly identify the fields potentially suitable for the

446 bonus payment (Table A.1), even if they were not otherwise knowledgeable about the

447 plant species chosen as indicators. According to their own assessment and based on

448 reactions to the indicator species brochure, few $(<5)$ farmers exhibited, or thought

449 someone else in their household had, sufficient knowledge to carry out the self-

450 monitoring of the indicator species at the time of the interviews. However, most

451 interviewees stressed that their professional background provided them with enough

452 know-how to successfully complete the task with supporting extension materials.

453 Though all farmers mentioned the need for extension services, most wanted the

454 training to be 'light' (it 'comes out of the budget and then there's less to distribute').

455 Most did not consider the indicator plant species brochure shown to them (Appendix

456 A) sufficient on its own for getting started. Rather, the farmers suggested introductory

457 hands-on training, contact information for expert support, online materials or even a

458 smartphone app for species identification. Several farmers suggested the measure

459 should be introduced in the obligatory continuing education meetings they attend.

460 Opinions about an appropriate sum for the bonus payment were influenced by

461 individuals' perceptions of the proposed measure as either a low-cost maintenance of 

possibly already suitable fields (low threshold) or establishment of new NMG (high threshold). Fifty euros was most frequently suggested as a minimum: 'If you already have the species and don't have to do anything, then small'. Two farmers expressed that the bonus 'shouldn't be too high', as it could then attract people who are willing to cheat to get the subsidy. At the other end of the spectrum was consideration of costs and forgone income: one suggestion was for the bonus to be equivalent to average income for a field crop, and two farmers suggested that it should be equal to subsidy for buffer zones (currently $400 € / \mathrm{ha}$ ).

The 17 fields visited during interviews fell into three groups according to the number of present indicator species (Table A.1). There were 12 sites (71\%) that would already qualify for the bonus payment, four sites $(24 \%)$ that might qualify under appropriate management (e.g. mowing of overgrown patches or bringing in the hay mass from another diverse field to seed), and one field (6\%) that would require long-term management investment (heavily overgrown on nutrient-rich soil).

\section{Reputation and public perception}

Perceived effects of the approach on reputation was mostly positive. Concerns were formulated as 'growing weeds', 'unmanaged sites', and 'bad farming'. Aesthetics of the overall farmland landscape and fields neighbouring others' properties elicited particular concern. Farmers suggested that some peers would reject the idea of farmers 'counting flowers'. Most farmers expressed that, though their peers' opinions matter to them, they make their own decisions. Some farmers also explained that attitudes change as new practices become normalised, and mentioned growing acceptance of organic agriculture as an example of how farmers' attitudes toward environmental practices may change over time. Farmers generally felt that this type of environmental conservation activity would be received positively by the general public, and may even improve reputation of farmers and farming by showing that farming 'isn't just intensive production'. A minority expressed the view that 'the public is always blaming farmers' and the measure may be perceived as 'more free subsidies' to farmers. 
494 We identified seven main themes in the responses by experts and officials: cost, 495 administrative capacity, verifying results, governance context, evidence of results, 496 farmer capacity, and misuse and cheating (Table 4). Public officials working with 497 administration and inspection of AES were most critical of the PBR approach. They 498 could not see how the new approach could fit into the current AES, or even any 499 reason for changing the existing system. One administrative expert noted that since 500 subsidies are no longer coupled to production, a basic attitude is that 'nobody expects 501 a result'. The gravest concerns were about ability to verify the results at the right time 502 and in a way compatible with EU requirements (Table 4). Also, the current capacity 503 of already overstretched personnel to monitor new things and learn new skills was 504 questioned.

505 Responses emphasised perceived administrative burden of the measure. Only one of 506 the four interviewees representing administration and inspection considered the 507 approach in terms of achieving agri-environment targets. None mentioned building of 508 farmer capacity or other aspects of cultural capital in their responses. Responses to 509 whether the proposed PBR scheme is better or worse than the existing management510 based measure were mostly noncommittal to negative. However, one official stated 511 that there may be contexts in which the results-based scheme is better but that 'the 512 plant species component alone wouldn't make the NMG measure better'. Two 513 officials stated that adding more management requirements to the existing NMG 514 scheme could achieve the biodiversity result aims of the proposed results-based 515 prototype. Some of the experts viewed the proposed PBR as a 'continuous growth' 516 model in which there was to be continuous increase in target species, which should be 517 measured in some way.

519 Table 4 Concerns about results-based approach amongst the experts, officials and advisors interviewed.

520 Number of interviewees commenting on each theme in (). The most strongly emphasised concerns

521 (frequency + amount of discussion) within and across themes are in bold.

\begin{tabular}{ll}
\hline Theme & Concerns \\
\hline Cost (5) & Could result in more required inspections \& more training, outside trainers; \\
& Fields would be divided into good \& bad, which would place demands for more \\
& funds; \\
& $\begin{array}{l}\text { Lowering basic payment to support the bonus payment would be unfair to } \\
\text { farmers. }\end{array}$
\end{tabular}


Administrative capacity

(4)

Verifying results (5)

Governance context (3)

Result? (3)

Farmer capacity (3)

Misuse \& Cheating (3)
High training threshold for inspectors to gain necessary skills/ indicator species knowledge.

Planning \& application in spring, species observation possible only in summer;

Farmer \& inspector must have same criteria and result;

Farmer self-reporting isn't reliable or accepted;

No biodiversity baseline info on the sites.

National programme must fit into EU framework/existing scheme structure;

Ministry has said no new 'norms'- aim is easing of existing burden.

\section{Is it better? Must have evidence.}

Farmers have to learn new skills;

Farmers have to also learn a new scheme.

'If it doesn't say what isn't allowed, then everything is allowed';

EU could require higher rate of inspections if cheating is discovered to be higher;

'Applicants want to maximise subsidies and will likely say they have the maximum-level of species needed'.

523 From the government side, the response from a Ministry of Agriculture representative

524 was relatively optimistic and was based on experience with many dramatic changes in

525 the working priorities and modes that the Ministry has seen in recent decades. The

526 respondent stressed that the ever-pressing expectations of society for improvements in

527 the state of the environment forces the administration to experiment with delivery of

528 results in cost-efficient ways.

529 Agri-extension advisors were the most supportive of the approach, although they also

530 acknowledged some risks similar to those raised by the administrators. The advisors

531 saw the results-based thinking as providing genuinely new tools for enhancing

532 biodiversity and landscape management in agricultural areas. Most respondents

533 wished to see examples of successful piloting of the approach with solid evidence on

534 performance and administrative costs.

\section{Discussion}

Suitability of the indicators for ecological targeting and as a guiding tool

538 The list of indicator species appeared to be suitable for identifying NMG with high

539 total species richness of vascular plants. By using seven indicator species as a 
threshold, the bonus payment could be channelled to the $10 \%$ of the NMG fields with nearly double mean species richness per plot compared to the scheme overall. As previous research has demonstrated, plant species richness and abundance of flowering plants in grassland habitats enhance, in turn, diversity and abundance of many other taxa, especially insects (Toivonen et al. 2016, Tscharntke et al. 2011, Siemann et al. 1998).

The process of developing the indicator species set for NMG was aided by availability of the nationwide species data for the vegetation type concerned. The data collection methods of the national survey differed from the proposed method in the prototype scheme, which means that the survey results are only indicative of possible occurrence of indicators under the PBR scheme. In the vegetation survey, the surveyed transect was of a fixed length and included field edges, which usually have more diverse vegetation than the middle parts of fields (Boatman et al. 2011). The initial monitoring format for the prototype scheme was occurrence of indicator species along a single transect across the field, which reduces the impacts of edges but, in most cases, increases the total monitored area. Site visits conducted with the interviewees showed that NMGs are sometimes heterogeneous, with patches of higher diversity or specific clusters of indicator plants. Thus, a monitoring approach accounting for such heterogeneity would likely increase the number of sites qualifying for the bonus. Practicality of such an approach is more complicated but could be addressed by, for example, GPS-coordinate marked 'hotspots'. Existing or trialled PBR schemes have taken various routes, with German Lander schemes requiring four reference species 'regularly present' in each third of the field and France's Prairies fleuries scheme using broad indicator genera in addition to individual species, and restricting the scheme to targeted priority areas only (Magda et. al. 2015).

Allen et al. (2014) stress that setting up an indicator threshold, such as number of indicator plant species, should not lead to a decline in ecological condition in the most biologically diverse sites. This can be prevented by having multiple indicator thresholds, or by ensuring that payments are dependent on the maintenance of baseline conditions. In our case, a management baseline of abstaining from chemical inputs serves the purpose. 
572 Prevalence of indicator species on NMG suggested by the farmers shows that farmers'

573 know-how of their fields (their potential conservation values often coinciding with

574 poor production values) seems to be a sufficient baseline understanding among

575 potential participants. Participant knowledge base is expected to increase with

576 appropriate extension materials and advisory services and through hands-on

577 experience. This is particularly important considering that, even after decades of

578 payments for environmental conservation, farmers currently lack the knowledge and

579 skills for managing for optimal biodiversity conservation.

580

581 Farmers' views on PBR approaches

582 The number of participants represents a very small sample and farmers represent only

583 one region and, therefore, we had no intention of deriving a statistically representative 584 picture for the country. The results of the interviews gave us only an indication of the 585 range, strength and commonality of views across the interviewed groups. Importantly, 586 however, the farmers engaged with the scheme idea at a broad scale by generalizing it 587 to Finland's agriculture politics/policy as a whole and to other production and farming 588 styles and conditions, and regardless of perceived applicability of the scheme to their 589 own farm or context.

590 The idea of results-based payment for biodiversity results was overwhelmingly 591 accepted by the farmers in our study. This finding is in line with both anecdotal and 592 published evidence from Germany, France and Ireland (Oppermann and Gujer 2003, 593 de Sainte Marie 2010, Matzdorf and Lorenz 2010, Schwarz and Morkvenas 2012, 594 Osbeck et al. 2013, Schroeder et al. 2013). In particular, farmers favour the flexibility 595 offered by the PBR measures over the frustrations experienced by the detailed 596 597 management instructions and inspections of conventional management-based 598 2010). Also, most of the farmers participating in an even more demanding auctioning approaches (Oppermann and Gujer 2003, de Sainte Marie 2010, Matzdorf and Lorenz 599 trial in Finland were supportive of the idea of linking payments to results 600 (Grammatikopoulou et al. 2013). The farmers' main concern with verification of 601 results (in this case meeting the indicator species qualification) is consistent with the 602 experiences in other countries (Oppermann and Gujer 2003, de Sainte Marie 2010, 603 Matzdorf and Lorenz 2010). 
604

605

606

607

608

609

610

611

612

613

614

615

616

617

618

619

620

621

622

623

624

625

626

627

628

629

630

631

632

633

634

635

The two farmers whose initial responses to the proposed scheme were negative placed their criticism firmly in the context of perceived problems of AES overall. They attributed the bureaucracy problem to larger structural problems of the subsidy system itself, as well as to lack of trust in the bureau tasked with oversight in Finland. This criticism echoes previous findings that farmers are frustrated by detailed management instructions and inspections (Kaljonen 2006) and is only nominally related to the PBR approach and the proposed scheme.

Studies accompanying trials or implementation of PBR measures cite a more meaningful engagement of farmers in adaptive management for best fit for their situation and context as a key success factor for such measures (Klimek et al. 2008, Swagermakers et al. 2009, Zabel and Roe 2009, Osbeck et al. 2013). Concurrently, adaptive management and self-monitoring supports and builds 'cultural capital' in environmental stewardship (Burton \& Swartz 2013, Lowe et al. 1997). In our study, such cultural capital potential was evident in e.g. farmers' express interest in best management practices and enthusiasm for the learning and sharing opportunities provided by the self-monitoring.

\section{Differences and similarities in farmer and expert stakeholder views}

Farmers, particularly those with 'equivocal' first impression of the proposed PBR bonus, and expert stakeholders brought up some similar concerns. Otherwise, they responded differently, with farmers mainly seeing opportunity and experts mainly seeing risk.

Each group considered how a novel approach might impact their own profession (e.g. skills, knowledge acquisition) and workload, but farmers also expressed values related to landscape, nature and agricultural production. Many of the farmers exhibited a high degree of knowledge regarding rules and structures governing AES and agriculture policy, and this was reflected in their concerns and questions on implementation of the bonus. We discovered during interviews that two of the farmers had formerly been employed in AES development or inspection. The former subsidy inspector's response was consistent with interviewed experts from the administrative sector. The farmer with several years experience in AES design-related tasks responded similarly to the extension advisory experts. 
636 Rejection by most of the experts of the PBR approach as incompatible with EU

637 Commission's framework is somewhat at odds with the fact that the approach is used

638 in other EU countries, although some of those programmes are paid from regional, not

639 EU funds (Allen et al. 2014). This reflects a currently low profile of the PBR

640 approach at the EU level. Farmer self-monitoring was also criticised as unacceptable

641 to the EU Commission, even though current action-based payments also rely on

642 farmers' self-reporting with only a possibility of inspection. The learning curve and

643 training needed for inspectors was also purported to be unreasonably high. However,

644 experiences with the PBR approach so far show that people administering measures

645 with PBR components believe that, on balance, measures focused on results are more

646 cost-effective than management-based schemes (Allen et al. 2014, Butler et al. 2010,

647 Matzdorf and Lorenz 2010, Groth 2009). Further, it could be argued that more

648 training for farm-level visits (inspectors) is needed regardless of approach: a recurring

649 criticism of the inspection process from farmers is that inspectors are critical but

650 unable to give advice for improvement and problem solving (Birge and Herzon 2014,

651 Seppänen and Helenius 2004). This study's finding that farmers wish now for more

652 advice on good management practices for NMG is in line with others that adequate

653 extension services are important to the success of programmes aiming for farmer

654 engagement in conservation, regardless of the approach (Schroeder et al. 2015, Allen

655 et al. 2014).

656 Farmers had more faith in their capacity to gain skills necessary for the self-

657 monitoring than the expert stakeholders involved in administration and governance.

658 The farmers' assessment of themselves in this respect is supported by studies

659 confirming enhanced ecological knowledge in several PBR measures (for example, de

660 Sainte Marie 2010).

661 Unlike many of the farmers, experts criticised but did not propose technical solutions

662 to the monitoring issue. They were more concerned with cheating, whereas the

663 majority of farmers who mentioned cheating mainly stated that people are not going

664 to go to great lengths to cheat for a small bonus payment ( $c f$. results in Klimek et al.

665 2008). Potential cheating was mentioned by experts in our study far more often than

666 achieving environmental benefits. There was little indication that the subsidy

667 administrators interviewed view farmers as partners in conservation or stakeholders

668 whose conservation skills and attitudes can be developed. These results show a need 
for orientation toward cultural capital thinking within the administrative structures if PBR measures are introduced.

\section{Experimenting for policy learning}

We cannot, based on this research, state that the PBR measure modification is per se better than the present management-based measure in terms of its effectiveness to deliver ecological quality. This would require a targeted study comparing the outcomes of two measure alternatives under comparable conditions. The degree to which agri-environment type measures perform for biodiversity benefits depends on a far greater range of factors than studied here (as reviewed in Allen et al. 2014). However, the approach explicitly encourages "innovation, self-help and mutual learning, and finding positive ways of harnessing the power of peer group pressure" (ibid pp. 115). Indeed, experiences from the French flowering meadows competitions indicate that the agro-ecological emphasis of combining agronomic and biodiversity aims result in a collective learning process for all participants (Magda et al. 2015).

Our results call for further experimentation aimed at policy learning. With specific recommendations from the EU for testing the result-based approaches as means for improving AES efficiency, the growing body of evidence that the PBR approach provides numerous benefits, and our findings showing farmer interest in the approach, the time might be ripe in Finland for piloting results-based payments for biodiversity management. The piloting should target different regions. Because agricultural policy is mandated on the national level, with only limited regional targeting, there is a general uniformity for policy implementation throughout the country. However, it is possible that new perspectives may be found in other regions and among other farming types due to factors that are not relevant to the cereal farmers in the Uusimaa region. Livestock farms have a larger range of options at their disposal for grasslands compared to non-livestock farms that may struggle with grazing or haying requirements of other schemes. Results may differ also in the regions with high levels of agricultural abandonment. Also other target biotopes, such as traditional or seminatural biotopes, should be tested for a result-based approach to policy delivery. Indicator development for other environmental targets, such as reducing nutrient runoff, require independent trials. 
701 Experimentation should incorporate systematic monitoring of the ecological and

702 economic efficacy of the PBR approach as compared to the conventional

703 management-based measures. Given the importance of farmer attitudes and

704 management practices to scheme outcome, these should also be assessed and

705 monitored. With respect to administrative officials, the experimentation, however,

706 calls for an experimental mind and a licence to fail (cf. Primmer and Hildén 2015).

707 According to our findings, such an experimental attitude might be the trickiest thing

708 to achieve in the current practice and framework of agri-environmental schemes (cf.

709 Kaljonen 2011).

\section{Conclusions}

712 The bonus scheme has the potential to target the most biologically diverse sites by 713 possible channelling of just $5 \%$ of the total current expenditure on the measure to 714 retention and management of parcels with nearly double mean species richness per 715 plot compared to the current scheme. This can be regarded as a high efficiency in 716 terms of environmental outcomes. The indicator species list also proved suitable for

717 identifying NMG with high total species richness of vascular plants and appeared 718 feasible in the eyes of the farmers.

719 Farmers were mainly positive about the PBR approach and the findings show a 720 possibility for developing farmer capacity and cultural capital in managing for 721 biodiversity conservation. Policy officials in charge of the implementation of the agri722 environmental schemes were the most critical towards the monitoring of the results723 based approach. Change from same-for-all management-based measures to payments 724 tailored by results will require new thinking from AES officials.

725 Further experimentation and piloting, in different regions and for more production 726 types, is needed before implementation of the results-based approach. According to 727 our results, the experiments should focus on finding a balance between self728 monitoring and inspection: verification should be able to take the heterogeneity of 729 NMG sites into account but must not be overly cumbersome for either farmers or 730 inspectors. Also, learning and capacity building for farmers and inspectors is needed. 731 Close co-operation with policy officials, farmers and researchers in designing and monitoring the experiments is needed for overcoming obstacles. Lessons learned in 
other countries may aid in finding solutions to issues brought up by the experts interviewed, including verification and compatibility with national and EU requirements.

\section{Acknowledgements}

We thank all the participants in the study and acknowledge funding of Emil Aaltonen Foundation for funding, Jenny and Antti Wihuri Foundation, and R. Erik Serlachius Foundations. Species data generation was funded by the Finnish Ministry of Agriculture and Forestry (Project Number 2589/311/2009). We thank the two anonymous reviewers who reviewed this manuscript.

\section{References}

Allen, B., Hart, K., Radley, G., Tucker, G., Keenleyside, C., Oppermann, R., Underwood, E., Menadue, H.,Poux, X., Beaufoy, G., Herzon, I., Povellato, A., Vanni, F., Pražan, J., Hudson, T., Yellachich, N., 2014. Biodiversity protection through results based remuneration of ecological achievement. Report Prepared for the European Commission, DG Environment. Institute for European Environmental Policy, London. 167 pp.

Arponen, A., Heikkinen, R.K., Paloniemi, R., Pöyry, J., Similä, J., Kuussaari, M., 2013. Improving conservation planning for semi-natural grasslands: integrating connectivity into agri-environment schemes. Biol Conserv 160, 234-241.

Boatman, N.D., Jones, N.E., Conyers, S.T., Pietravalle, S., 2011. Development of plant communities on set-aside in England. Agr Ecosys Environ 143, 8-19.

Batáry, P., Dicks, L.V., Kleijn, D., \& Sutherland, W.J., 2015. The role of agrienvironment schemes in conservation and environmental management. Conserv Biol 29, 1006-1016.

Battin, J., 2004. When good animals love bad habitats: ecological traps and the conservation of animal populations. Conserv Biol 18,1482-1491.

Berniger, K., 2012. Payment for ecosystem services and outcome-based approach in agri-environment schemes: Can we find a way forward? Baltic Compass Seminar report. Lohja, Finland. 12 pp.

http://www.balticcompass.org/PDF/Reports/PES Finland seminarreport.pdf [accessed 4.8.2016]

Bertke, E., Klimek, S. \& Wittig, B., 2008. Developing result-orientated payment schemes for environmental services in grasslands: results from two case studies in North-western Germany. Biodiversity 9, 91-95.

Birge, T. \& Herzon, I. 2014. Farmer and landowner motivations and experiences in managing rare semi-natural biotopes: A case from Finland. Land Use Policy 41, 128 137.

Braun, V. \& Clarke, V., 2006. Using thematic analysis in psychology. Qual Res 
Psycol. 3(2), 77-101.

774 Burren Life Programme, 2015. http://burrenlife.com/the-burren/ [accessed 3.3.2016]

775 Burton, R.J.F. \& Paragahawewa, U., 2011. Creating culturally sustainable agr-

776 environmental schemes. J Rural Stud 27, 95-104.

777 Burton, R.J.F \& Schwartz, G., 2013 Result-oriented agri-environmental schemes in

778 Europe and their potential for promoting behavioural change. Land Use Policy 30,

779 628-641.

780 Butler, S.J., Boccaccio, I., Gregory, R.D., Vorisek, P. \& Norris, K., 2010. Quantifying

781 the impact of landuse change to European farmland bird populations. Agr Ecosys

782 Environ 137, 348-357.

783 Creswell, J. W., Plano Clark, V. L., Gutmann, M., \& Hanson, W. (2003). Advanced

784 mixed methods research designs. In A. Tashakkori \& C. Teddlie (Eds.), Handbook of

785 mixed methods in social and behavioral research (pp. 209-240). Thousand Oaks, CA:

786 Sage.

787 De Sainte Marie, S., 2010. Let Hundreds of Flowers Bloom? The Rising of Local

788 Authorities and the Governance of Agricultural Affairs in the French Countryside.

789 Paper presented at the 50th Congress of the European Regional Science Association

790 in Jönköping (Sweden), 19-23 August 2010.

791 De Sainte Marie, C., 2014. Rethinking agri-environmental schemes. A result-oriented 792 approach to the management of species-rich grasslands in France. J Environ Plann

793 Man 57, 704-719.

794 de Snoo, G.R., Herzon, I, Staats, H., Burton, Rob J.F., Schindler, S., van Dijk, J.,

795 Lokhorst, A.M., Bullock, J., Lobley, M., Wrbka, T., Schwarz, G., Musters, C.J.M.,

796 2012. Towards Effective Nature Conservation on Farmland: Making Farmers Matter.

797 Conserv Lett 6, 66-72.

798 EEA (European Environment Agency), 2004. High nature value farmland:

799 Characteristics, trends and policy challenges. Copenhagen. 31 pp.

800 http://www.eea.europa.eu/publications/report_2004_1 [accessed 15.12.2015]

801 EC (European Commission), 2015a. MEKA programme B4 - species rich grassland

802 scheme - Germany, Baden-Württemberg. Last updated: 29.05.2015.

803 http://ec.europa.eu/environment/nature/rbaps/fiche/index_en.htm [accessed

804 06.03.2016]

805 EC (European Commission) 2015b. EU agriculture spending: focused on results.

806 September 2015. 8pp. http://ec.europa.eu/agriculture/cap-funding/pdf/cap-spending-

807 09-2015_en.pdf [accessed 06.03.2016]

808 European Court of Auditors, 2011. Is Agri-environment support well designed and

809 managed? Special report no. 7/2011. European Union, Luxembourg. 75 pp.

810 http://eca.europa.eu/portal/pls/portal/docs/1/8772726.PDF [accessed 15.12.2015]

811 European Network for Rural Development and European Commission, 2010. Report

812 on the Contribution of the European Network for Rural Development to the Public

813 debate on the Common Agricultural Policy after 2013 (13/07/2010). European

814 Commission, Brussels. http://enrd.ec.europa.eu/enrd-static/fms/pdf/DAB81B97-

815 9E9B-F50F-6F18-C76EBF6B1A4A.pdf [accessed 24.06.11].

816 Grammatikopoulou, I., Pouta, E., \& Iho, A., 2013. Willingness of farmers to 
participate in agri-environmental auctions in Finland. Food Econ 9, 215-230.

818 Groth, M., 2009. The transferability and performance of payment-by-results

819 biodiversity conservation procurement auctions: empirical evidence from

820

821

822

823

824

825

826

827

828

829

830

831

832

833

834

835

836

837

838

839

840

841

842

843

844

845

846

847

848

849

850

851

852

853

854

855

856

857

858

northernmost Germany. Working Paper Series in Economics, University of Luneburg. 35 pp. http://www.uni-lueneburg.de/fb2/vwl/papers/wp_119_Upload.pdf [accessed 15.12.2015]

Helenius, J. \& Seppänen, L., 2004. Do inspection practices in organic agriculture serve organic values? A case study from Finland. Agr Hum Values 21, 1-13.

Herzon, I. \& Mikk, M., 2008. Farmers' perceptions of biodiversity and their willingness to enhance it through agri-environment schemes: A comparative study from Estonia and Finland. J Nat Conserv 15, 10-25.

Herzon, I., Toivonen, M., Kankaanpää, O., Mäkinen, T., Delasalle, M., Le Barh, C., Swiderski, C. \& Helenius, J., 2012. Luonnonhoitopeltojen ympäristöhyödyt. In: Heliölä, J. \& Herzon, I. (eds.) Maatilan luontoarvojen mittaaminen luonnonhoitopellot, erityistukialueet ja tilataso. Suomen ympäristö 26/2012, Luonto, 91 pp. Suomen ympäristökeskus. (In Finnish with English summary).

Hämet-Ahti, L., Suominen, J., Ulvinen, T. \& Uotila, P., (Eds.) 1998. Retkeilykasvio (Field Flora of Finland), fourth ed. Finnish Museum of Natural History, Botanical Museum, Helsinki. 656 pp.

IBM Corp, 2015. IBM SPSS Statistics for Windows, Version 23. Armonk, NY: IBM Corp.

Kaljonen, M. 2006. Co-construction of agency and environmental management. The case of agri-environmental policy implementation at the Finnish farms. J Rural Stud 22: $205-216$.

Kaljonen, M., 2008. Bringing back the lost biotopes. The practice of regional biodiversity management planning in Finland. J Environ Plann Manag 10, 113-132.

Kaljonen, M., 2011. Caught between standardization and complexity. Study on the institutional ambiguities of agri-environmental policy implementation in Finland. Acta Universitatis Tamperensis 1594. University of Tampere. Tampere University Press, Tampere. $121 \mathrm{pp}$.

Keenleyside C., Allen B., Hart K., Menadue H., Stefanova V., Prazan J., Herzon I., Clement T., Povellato A., Maciejczak M., Boatman N., 2011. Delivering environmental benefits through entry level agri-environment schemes in the EU. Report Prepared for DG Environment. Institute for European Environmental Policy: London.

Kemppainen, R. \& Lehtomaa, L., 2009. The state and targets for traditional biotopes. The national evaluation of the regional management plans for traditional biotopes. [Perinnebiotooppien hoidon tila ja tavoitteet]. The West-South Regional Environment Center 2/2009.

Kleijn, D., Rundlöf, M., Scheper, J., Smith, H.G., Tscharntke, T., 2011. Does conservation on farmland contribute to halting the biodiversity decline? Trends Ecol Evol 26, 474-481. 
Klimek, S., Richter gen. Kemmermann, A., Steinmann, H-H., Freese, J., Isselstein, J., 2008. Rewarding farmers for delivering vascular plant diversity in managed grasslands: A transdisciplinary case-study approach. Biol Conserv 141, 2888-2897.

Kuussaari, M., Heliölä, J., Herzon, I., Tiainen, J., Ekroos, J. 2013. Luonnon monimuotoisuus maatalousalueilla. Aakkula, J. ja Leppänen, J. (toimit.) Maatalouden ympäristötuen vaikuttavuuden seurantatutkimus (MYTVAS 3). Maa- ja metsätalousministeriö 3/2014. Suomen Yliopistopaino Oy, Helsinki. pp. 86-132. (in Finnish). [Biodiversity in the agricultural environment. In: Follow-up study on the impacts of agri-environment measures (MYTVAS 3) - Final report].

Lowe, P., Clark, J., Seymour, S., Ward, N., 1997. Moralizing the environment. Countryside change, farming and pollution. UCL Press, London 224pp.

Magda, D., de St. Marie, C., Plantureux, S., Agreil, C., Amioud, B., Mestelan, P., Mihout, S., 2015. Integrating agricultural and ecological goals into the management of species-rich grasslands_ learning from the flowering meadows competition in France. Environ Manage 56,1053-1064.

Marggraf, R., 2003. Comparative assessment of agri-environment programmes in federal states of Germany. Agr Ecosys Environ 98, 507-516.

Matzdorf, B., Kaiser, T., Rohner, M-S., 2008. Developing biodiversity indicators to design efficient agri-environmental schemes for extensively used grassland. Ecol Indic 8, 256-269.

Matzdorf, B. \& Lorenz, J., 2010. How cost-effective are result-oriented agrienvironmental measures? An empirical analysis in Germany. Land Use Policy 27, $535-544$.

McKenzie, A.J., Emery, S.B., Franks, J.R. \& Whittingham, M.J., 2013. Landscapescale conservation: collaborative agri-environment schemes could benefit both biodiversity and ecosystem services, but will farmers be willing to participate? J Appl Biol 50(5), 1274-1280.

Natural Resources Institute Finland 2015. Utilized agricultural area 2015. http://stat.luke.fi/en/utilised-agricultural-area [accessed 30.02.2016]

Natural Resources Institute Finland, 2016. Statistics database http://statdb.luke.fi/PXWeb/pxweb/en/LUKE/LUKE_02\%20Maatalous_02\%20Rak enne_02\%20Maatalous$\% 20 \mathrm{ja} \% 20$ puutarhayritysten $\% 20 \mathrm{rakenne} /$ tablelist=true \&rxid=001bc7da-70f4-47c4a6c2-c9100d8b50db [accessed 7.10.2016].

Niemi, J. \& Ahlstedt, J., (Eds). 2014. Suomen maatalous ja maaseutuelinkeinot 2014. MTT Taloustutkimus, julkaisuja 115. MTT Taloustutkimus. (in Finnish). [Finnish agriculture and rural livelihoods 2014]. https://portal.mtt.fi/portal/page/portal/mtt/mtt/julkaisut/suomenmaatalousjamaaseutuel inkeinot/jul115 SM2014.pdf [accessed 15.12.2015]

Oppermann, R. \& Gujer, H. U., (Eds.) 2003. Artenreiches Grünland-Bewerten Und Fördern: MEKA Und ÖQV in Der Praxis. (in German). Ulmer, Eugen, GmbH \& Co. $199 \mathrm{pp}$.

Osbeck, M., Schwarz, G. \& Morkvenas, Z., 2013. Dialogue on ecosystem services, payments and outcome-based approach. Background Brief. SEI Stockholm Environment Institute. 16 p. http://www.sei- 
international.org/mediamanager/documents/Publications/Air-land-waterresources/BC-2013-PES-Background-Brief.pdf

Primmer, E. \& Hildén, M., 2015. Experimentation and sustainability: a paradox or an opportunity for institutional learning? Ratkaisuja blog, Finnish Environment Institute. http://www.syke.fi/fiFI/SYKE_Info/Viestintaaineistot/Ratkaisujablogi/Eeva_Primmer_Mikael_Hilden_Ex perimentati\%2836063\%29 [accessed 15.12.2015]

Pykälä, J., 2001. Perinteinen karjatalous luonnon monimuotoisuuden ylläpitäjänä. Suomen ympäristö 495. Helsinki: Suomen ympäristökeskus. 205 pp.

Rassi, P., Hyvärinen, E., Juslén, A., Mannerkoski, I. (Eds.) 2010. The 2010 Red List of Finnish Species. Ministry of the Environment and Finnish Environment Institute, Helsinki. 685 pp.

Riedel S., Walter T., Herzog F., 2012. Switzerland: Chapter 4. In: High Nature Value Farming in Europe. Ubstadt-Weiher, Publ. R. Oppermann, G. Beaufoy \& G. Jones, Verlag Regionalkultur. 2012, p. 420-433. ISBN 978-3-89735-657-3.

Schroeder, L.A., Isselstein, J., Chaplin, S., Peel, S., 2013. Agri-environment schemes: Farmers' acceptance and perception of potential 'Payment by Result s' in grasslandA case study in England. Land Use Policy 32, 134-144.

Schroeder, L.A., Chaplin, S., Isselstein, J., 2015. What influences farmers' acceptance of agri-environment schemes? An ex-post application of the 'Theory of Planned Behaviour'. Landbauforschung 65, 15-28.

Seppänen, L. \& Helenius, J., 2004. Do inspection practices in organic agriculture serve organic values? A case study from Finland. Agric. Human Values 21, 1-13.

Siemann, E., Tilman, D., Haarstad, J., Ritchie, M., 1998. Experimental tests of the dependence of arthropod diversity on plant diversity. Am Nat 152, 738-750.

Swagemakers, P., Wiskerke, H., Van Der Ploeg, J.D., 2009. Linking birds, fields and farmers. J Environ Manage 90, 185-192.

Toivonen, M., Herzon, I., Helenius, J., 2013. Environmental Fallows as a new policy tool to safeguard farmland biodiversity in Finland. Biol Conserv 159, 355-366.

Toivonen, M., Herzon, I., Kuussaari, M., 2015. Differing effects of fallow type and landscape structure on the occurrence of plants, pollinators and birds on environmental fallows in Finland. Biol Conserv 181, 36-43.

Toivonen, M., Herzon, I. \& Kuussaari, M. 2016. Community composition of butterflies and bumblebees in fallows: niche breadth and dispersal capacity modify responses to fallow type and landscape. J Insect Conserv 20, 23-34.

Tscharntke, T., Batáry, P., Dormann, C.F., 2011. Set-aside management: How do succession, sowing patterns and landscape context affect biodiversity? Agr Ecosys Environ 143, 37-44.

Whittingham, M.J., 2007. Will agri-environment schemes deliver substantial gain, and if not why not? J App Ecol 44, 1-5.

Wilson, G.A., Hart, K., 2001. Farmer participation in agri-environmental schemes: towards conservation-oriented thinking? Sociol Ruralis. 41 (2), 254-274. 
946 Yin, R. 2014. Case Study Research. Design and methods. $5^{\text {th }}$ Edition. Thousand Oaks, 947 CA: Sage Publications Inc.

948 Zabel, A. \& Roe, B., 2009. Optimal design of pro-conservation incentives. Ecol Econ $94969,126-134$.

950 


\section{Appendices}

Appendix A 1. Leaflet for farmers with the indicator plant species used in the farmer interviews about the hypothetical bonus payment for nature management fields. English common names added to leaflet for publication.

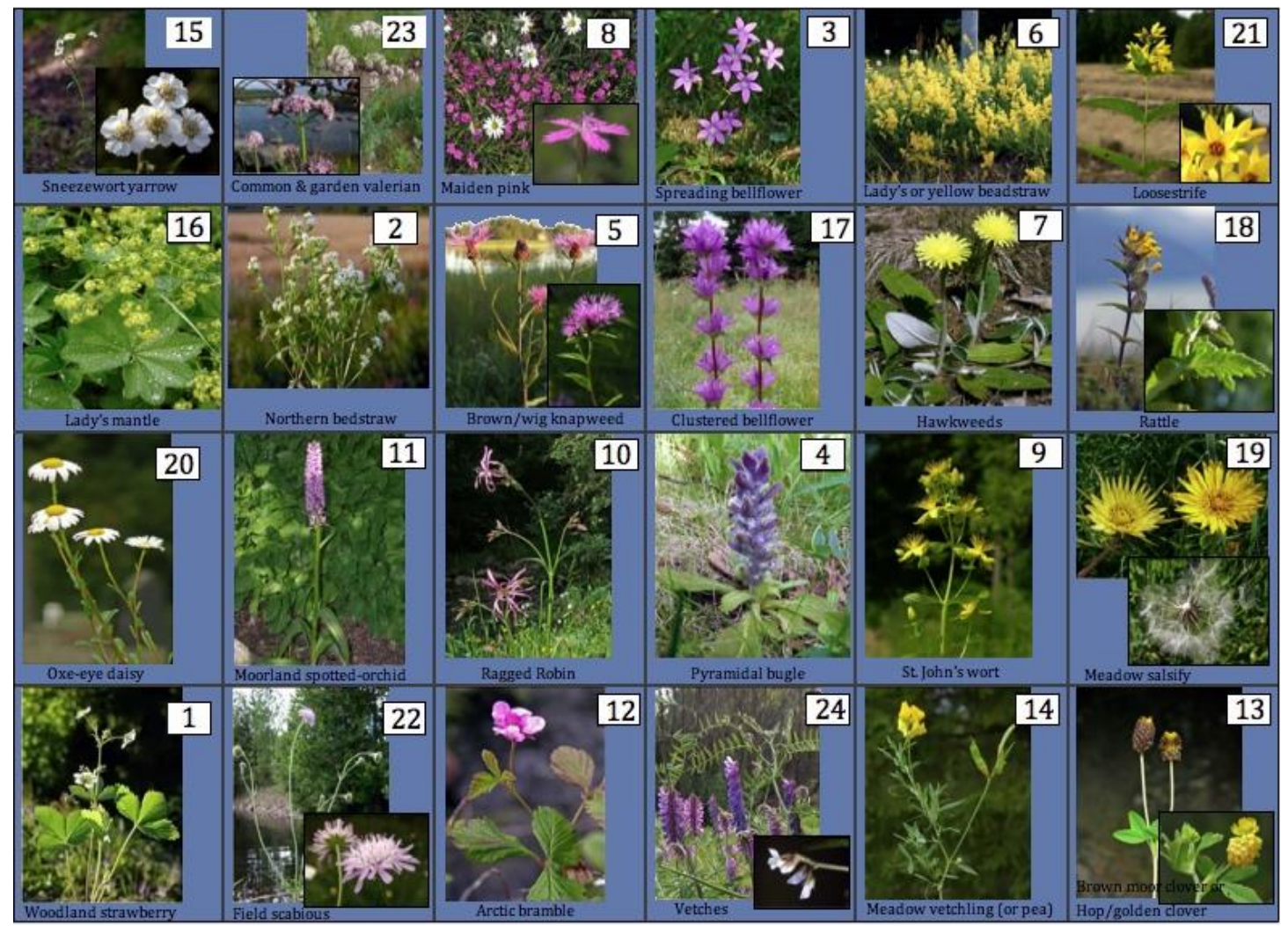

Photographer (C) Jouko Lehmuskallio /www.luontoportti.fi /www.naturegate.net. Photographs used with permission.

Appendix A 2 Leaflet text for farmers describing the prototype bonus scheme. Farmers were provided with common names for indicator species (left hand side). These correspond to the numbers on the photo guide (Appendix A 1). Space is provided for recording any indicator species found. Appendices A 1 and 2 are translations of the original Finnish language leaflet. 


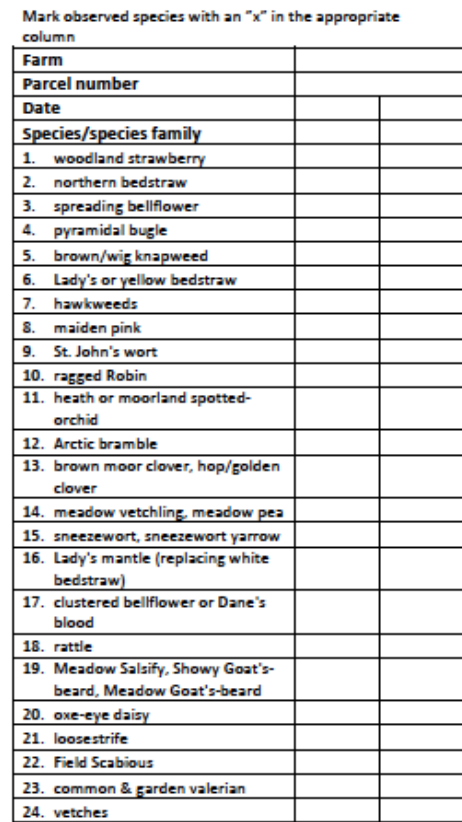
$(\mathrm{n}=17)$.
What: The goal of this proposed agri-environmental subsidy (AES) maintainencs and/or improvement of plal species diversity in Nature Management Fields (NMG). Improved plant species diversity would also support other species biodiversity. The hypothetical new payment model consists of a basic payment and a bonus payment dependent upon the presence of specific plant species on NMG. Bonus payment sum is $x$.

Why: NMG have been shown to be one of the most effective AES actions for maintaining regular natural biodiversity in the Finnish agricultural environment. Many NMG are old fallows and are located on lowproduction fields. Conversely, the flora of many NMG resemble production grassland and are used for fodde production. in the new measure presented, basic payment for NMO would remain $1206 /$ a An additiont bonus payment would be paid for species-rich parcels as an incentive for their maintenance.

In the proposed model, the landowner would have the freedom to choose how the NMG parcel is managed. This would include management actions for how to increase biodiversity including, for example, whether, hc and when to mow.

How: Bonus payment would be available for parcels with a minumum $Y$ species from the 24 "indicator species" list. The list includes easy-to-identify species from NMG on with varied soil types and habitat conditions throughout Finland

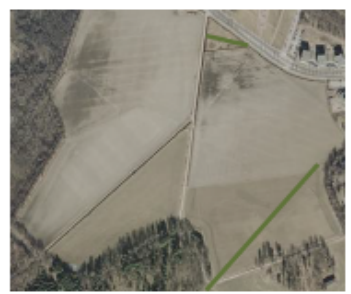

Species observation would by conducted by walking the length the NMG parcel in a straight line at its longest transect and fillin in a form for all indicator species observed within a 1 meter distance of the transect. The best time for conducting the observation transects is July when the majority of the species a in flower.

The compensation application would be submitted together wit the other AES tapplications. Indicator species observation woul be conducted twice during the 5 -year agreement period.

official inspection would take place during the same inspection visits as for other AES. Inspection would be done using the same observation method as that used by the farmers.

These 24 plant species on the left are indicative of diverse grassland flora and are the indicator species for th proposed bonus scheme.

Table A 1. List of 24 indicator species and their occurrence (in percent) on the nature management grasslands $(\mathrm{n}=104)$ (Toivonen et al. 2013), and, in brackets, on old nature management grasslands $(\mathrm{n}=20)$ (Toivonen et al. 2015). Ease to recognise is assessed by the authors for a species or group of related species. Habitat after Hämet-Ahti et al. (1998). Status is according to the national Red list (Rassi et al. 2010) and positive indicator of diverse grassland vegetation after Pykälä et al. (2001). Percentage of registrations is during field visits with farmers in connections to interviews in this study

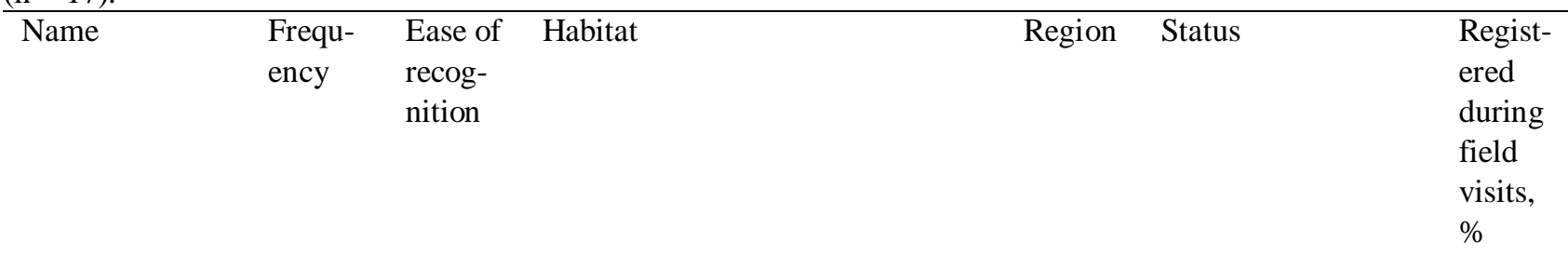

\begin{tabular}{|c|c|c|c|c|c|c|}
\hline $\begin{array}{l}\text { Achillea } \\
\text { ptarmica }\end{array}$ & $36(50)$ & 1 & Meadows, boundaries & & & 41 \\
\hline $\begin{array}{l}\text { Ajuga } \\
\text { pyramidalis }\end{array}$ & $0(5)$ & 3 & Meadows, forest edges & South & $\begin{array}{l}\text { Near threatened, } \\
\text { positive indicator }\end{array}$ & 0 \\
\hline Alchemilla spp. & $14(35)$ & 2 & Meadows, boundaries & & & 65 \\
\hline $\begin{array}{l}\text { Campanula } \\
\text { glomerata }\end{array}$ & $3(5)$ & 3 & Meadows, forest edges & East & Positive indicator & 12 \\
\hline $\begin{array}{l}\text { Campanula } \\
\text { patula } 1 /^{2} \\
\text { persicifolia }^{2}\end{array}$ & $34(70)$ & 2 & $\begin{array}{l}{ }^{1} \text { Meadows, boundaries, fallows } \\
{ }^{2} \text { Lush meadows }\end{array}$ & $\begin{array}{l}2 \\
\text { South- } \\
\text { West }\end{array}$ & ${ }^{2}$ Positive indicator & 82 \\
\hline $\begin{array}{l}\text { Centaurea } \\
\text { jacea }^{1} / \\
\text { phrygia }^{2}\end{array}$ & $7(30)$ & 2 & $\begin{array}{l}{ }^{1} \text { Dry meadows, boundaries } \\
{ }^{2} \text { Meadows, boundaries }\end{array}$ & $\begin{array}{l}{ }^{1} \text { South } \\
{ }^{2} \text { East }\end{array}$ & Positive indicator & 47 \\
\hline Dactylorhiza & $0(5)$ & 3 & Moist meadows, bogs & & ${ }^{1}$ Vulnerable & 0 \\
\hline
\end{tabular}




\begin{tabular}{|c|c|c|c|c|c|c|}
\hline $\begin{array}{l}\text { Dianthus } \\
\text { deltoides }\end{array}$ & $2(10)$ & 3 & Dry meadows, boundaries & & $\begin{array}{l}\text { Near threatened, } \\
\text { positive indicator }\end{array}$ & 18 \\
\hline Fragaria vesca & $3(30)$ & 2 & Meadows, boundaries & & Positive indicator & 24 \\
\hline Galium boreale & $10(0)$ & 3 & Meadows, forest edges & & Positive indicator & 41 \\
\hline Galium verum & $0(10)$ & 2 & Dry meadows, boundaries & $\begin{array}{l}\text { South- } \\
\text { West }\end{array}$ & $\begin{array}{l}\text { Vulnerable, positive } \\
\text { indicator }\end{array}$ & 6 \\
\hline $\begin{array}{l}\text { Hypericum } \\
\text { maculatum }^{1} / \\
\text { perforatum }^{2}\end{array}$ & $25(50)$ & 2 & $\begin{array}{l}{ }^{1} \text { Meadows, forest edges } \\
{ }^{2} \text { Rocky hills, juniper groves, } \\
\text { boundaries }\end{array}$ & ${ }^{2}$ South & ${ }^{2}$ Positive indicator & 53 \\
\hline $\begin{array}{l}\text { Knautia } \\
\text { arvensis }^{1} / \\
\text { Succisa } \\
\text { pratensis }^{2}\end{array}$ & 0 & 3 & Meadows, boundaries, fallows & $\begin{array}{l}{ }^{1} \text { East } \\
2 \\
\text { South- } \\
\text { West }\end{array}$ & Positive indicator & 6 \\
\hline $\begin{array}{l}\text { Lathyrus } \\
\text { pratensis }\end{array}$ & $49(90)$ & 1 & Meadows, boundaries, hay fields & & Positive indicator & 94 \\
\hline $\begin{array}{l}\text { Leucanthemum } \\
\text { vulgare }\end{array}$ & $18(50)$ & 1 & $\begin{array}{l}\text { Meadows, boundaries, forest } \\
\text { edges }\end{array}$ & & Positive indicator & 65 \\
\hline $\begin{array}{l}\text { Lychnis flos- } \\
\text { cuculi }\end{array}$ & $3(5)$ & 3 & $\begin{array}{l}\text { Damp meadows, shores, springs, } \\
\text { ditches }\end{array}$ & & Positive indicator & 18 \\
\hline Lysimachia spp. & $11(15)$ & 2 & $\begin{array}{l}\text { Shores, damp meadows, ditches, } \\
\text { swamps }\end{array}$ & & & 12 \\
\hline $\begin{array}{l}\text { Pilosella/Hiera } \\
\text { cium group }\end{array}$ & $17(15)$ & 3 & $\begin{array}{l}\text { Dry meadows, boundaries, forest } \\
\text { margins, open forests, shores, } \\
\text { rocky outcrops }\end{array}$ & & & 18 \\
\hline $\begin{array}{l}\text { Rhinanthus } \\
\text { serotinus }^{1} / \\
\text { minor }^{2}\end{array}$ & $11(10)$ & 3 & $\begin{array}{l}{ }^{1} \text { Boundaries, fallows } \\
{ }^{2} \text { Boundaries, meadows }\end{array}$ & & Positive indicator & 6 \\
\hline Rubus arcticus & 4 & 1 & Damp meadows, boundaries & Central & Positive indicator & 0 \\
\hline $\begin{array}{l}\text { Tragopogon } \\
\text { pratensis }\end{array}$ & $1(20)$ & 2 & $\begin{array}{l}\text { Railway embankments, roadsides, } \\
\text { field margins }\end{array}$ & South & & 0 \\
\hline $\begin{array}{l}\text { "Yellow } \\
\text { clover" } \\
\text { Trifolium } \\
\text { aureum1 / } \\
\text { spadiceum² }\end{array}$ & $2(15)$ & 3 & $\begin{array}{l}{ }^{1} \text { Dry meadows } \\
{ }^{2} \text { Meadows }\end{array}$ & ${ }^{1}$ East & $\begin{array}{l}\text { Near threatened, } \\
\text { positive indicator }\end{array}$ & 29 \\
\hline $\begin{array}{l}\text { Valeriana } \\
\text { sambucifolia }^{1} / \\
\text { officinalis }^{2}\end{array}$ & $8(5)$ & 2 & $\begin{array}{l}\text { Shore meadows, stream banks, } \\
\text { fallows, forest-edges }\end{array}$ & 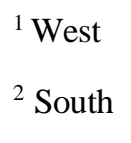 & & 29 \\
\hline Vicia spp. & $74(85)$ & 1 & $\begin{array}{l}\text { Meadows, fields, boundaries, } \\
\text { shores }\end{array}$ & & & 100 \\
\hline
\end{tabular}


Table A 2. Criteria for inclusion and exclusion for indicator species list

\begin{tabular}{ll}
\hline Included species: & Examples \\
\hline Mainly ubiquitous by geographical coverage and growing conditions & Leucanthemum vulgare, Achillea ptarmica \\
$\begin{array}{l}\text { Some specific to limited parts of the country and in specific abiotic } \\
\text { conditions (incl. wet sites along coastal and inland waters, fields with } \\
\text { numerous open ditches, and dry and nutrient-poor sandy soil sites). }\end{array}$ & $\begin{array}{l}\text { Valeriana sambucifolia/officinalis, } \\
\text { Dactylorhiza incarnate/maculata, Rubus } \\
\text { arcticus }\end{array}$ \\
$\begin{array}{l}\text { Some commonly occurring on NMG fields } \\
\text { Some of high conservation value occurring only occasionally in old } \\
\text { grassland vegetation. }\end{array}$ & Lathyrus pratensis, Vicia spp. \\
Excluded species: & Ajugramidalis, Dianthus deltoides \\
$\begin{array}{l}\text { Tolerant of high management intensity (either high soil fertility or } \\
\text { mowing/grazing pressure) }\end{array}$ & Urtica dioica, Trifolium repens \\
Found almost at every focus field type & \\
Noxious weeds & Achillea millefolium \\
Difficult to identify & Cirsium arvense, Equisetum arvense
\end{tabular}

Prior to interview questions, interviewee read an introduction to the research text to interviewees, asked if they had any questions before beginning, and secured permission to record the interview.

\section{Background}

a. Personal: sex, age, highest level of education, participation or membership in hunting/agricultural/environmental orgs.

b. Farm: farm size (ha), organic or conventional, hunting on farm, honey production on farm, on-farm income generation in addition to farming (e.g. tourism, direct sales, courses, etc).

c. Existing or past voluntary environmental subsidies: Nature management grassland (research focus): general area and history, how far from main farm (visible or 'hidden'), main reasons for scheme participation; other nature management fields \& biodiversity fields (incl. traditional rural biotopes, buffer zones, catch crops, game field, etc), any other 'special' subsidies; possible impact of the 'greening' requirement on nature management grassland.

\section{Payment-by-results bonus prototype}

a. Introduce prototype (leaflet text \& indicator species photos)

b. First impressions: interest in participating in scheme or not (reasons)

c. Open questions: perceived risks; requirements for success (e.g. extension services, selfmonitoring, inspection); necessary skills- do you have those skills?; affect on reputation- peer and society; own ideas to achieve similar/better result; other views, including on fairness and effectiveness of proposed scheme, impact on workload, etc.

\section{Attitude}

a. 'Good Farmer': What is a 'good farmer'/ 'good farming'? Is nature management grassland suitable to 'good farmer/farming'?

b. Nature stewardship: non-production activities farmer/ farm family engages in for nature, landscape management (e.g. nesting boxes for birds constructed wetland, hunting of invasive species, etc.); 'extra' activities to reduce farming impact on nature (e.g. checking for birds' nests before spring tractor work on the field). 
c. Farm natural history: Changes over time, expected changes for future.

d. Education: continuing education courses, activities, professional competitions or awards.

e. Social network: Are opinions of peers important to you? How might peers view this scheme or your participation in it? Affect on your actions?

Agri-environmental subsidy effect on farm income: Agri-environmental subsidy as a percentage of farm's total income.

Appendix C. Experts and officials ('expert stakeholders') interview guide

\section{Introduction text}

1010

In Finland, the agri-environment scheme (AES) is entirely based on prescribed management actions, and the payment amount is compensation based on calculations of real costs and lost income. Thus, the system lacks any incentive mechanism for achieving better results or applying the most appropriate site-specific management. An alternative is results-based payment where payment is partially or fully tied to results. The European Commission and Parliament are interested in this option and funded a report on it: (Biodiversity protection through results based remuneration of ecological achievement http://ec.europa.eu/environment/nature/rbaps/index_en.htm).

The aim of this research is to clarify how Finland could employ the results-based payment approach for biodiversity conservation. In the study we develop a hypothetical results-based prototype and interview farmers and representatives of other expert stakeholder groups.

Nature management grassland (NMG) measure is used in the study as an example of how a possible results-based measure could be applied as an incentive for biodiversity management. Nature management grasslands have been shown to be one of the most effective AES measures for maintenance of biodiversity in the typical farmland environs in Finland. The measure is quite popular in Finland. Previous research shows that plant species richness varies on NMG parcels from between 5 and 50 species (in transect counts). Appropriate management for specific parcel contexts and farmer capacity would help in achieving results.

\section{General}

1. Why, in your opinion, is results-based payment not used in Finland? Please provide any references you may have to support your opinion.

2. Does your professional group view the results-based payment approach positively or negatively in Finland? Other groups (farmers, governance, inspectors, advisors, etc). Is there evidence of this?

3. How broad (e.g. political) prerequisites would have to be realised for results-based approach to achieve support in Finland?

\section{Payment-by-results bonus prototype}

Present prototype (leaflet of indicator species) and

\section{Specific opinions}

1. From your perspective, what risks do you see with the results-based approach?

2. What prerequisites would you place on the approach, e.g extension services, self-monitoring, external inspection, etc.

3. In your opinion, are any specific skills needed in order to achieve the goals of the proposed measure? Do you have those skills?

4. In your opinion, does the approach strengthen or weaken AES reputation/ public perception in Finland?

5. Would the proposed results-based measure work better or worse than the existing management-based NMG measure in Finland? Please, explain your response.

1049

IV Key results from farmer interviews.

\section{Any further comments or questions}

